\title{
Neo-Eurasianism in Russian Foreign Policy: Echoes from the Past or Compromise with the Future?
}

\author{
Aryanta Nugraha \\ Department of International Relations FISIP UPN "Veteran" \\ Yogyakarta
}

\begin{abstract}
With its growing geopolitical inclination, Russian foreign policy has been considered as a resurgence of Eurasianism (Neo-Eurasianism). Notwithstanding its strong geopolitical sense, Eurasianism is multifaceted concept. It is often associated with philosophical thinking, cultural and political doctrines which changed over time and yet full of contradictions. This article seeks to find out the influence of Neo-Eurasianism in Russian foreign policy. Tracing back the idea of Eurasianism from historical perspective and employing Graham Smith classification on school of Eurasianism, this article argues that the rise of Neo-Eurasianism in Russia is driven by the needs to define and strengthen the spheres of influences. It is mainly motivated by ethnocentric sentiments to expand the sphere of influences across the border as a safeguard and protection. Neo-Eurasianism compromises building a foreign policy consensus based on political culture and national awareness.
\end{abstract}

Keywords: Eurasianism, Neo-Eurasianism, Russian Foreign Policy

Semakin condong ke geopolitik, politik luar negeri Rusia dipandang sebagai kebangkitan kembali Eurasianisme (Neo-Eurasianisme). Meskipun memiliki nuansa geopolitik yang kuat, Eurasianisme merupakan konsep yang memiliki banyak fitur, dikaitkan dengan filsafat politik, pemikiran budaya dan doktrin politik, meskipun penuh kontroversi. Artikel ini berupaya memahami pengaruh Eurasianisme dalam politik luar negeri Rusia. Melacak ide Eurasianisme melalui studi sejarah dan klasifikasi Graham Smith mengenai tiga pemikiran Eurasianisme, penulis berpendapat Neo-Eurasianisme tidak didorong oleh obsesi imperial, namun sentimen ethnosentrisme dan keinginan memperluas wilayah pengaruh sebagai sarana untuk melindungi identitas wilayahnya. Neo-Eurasianisme merupakan bentuk kompromi untuk membangun konsensus dalam politik luar negeri berbasis budaya politik dan kesadaran nasional.

Kata-Kata Kunci: Eurasianisme, Neo-Eurasianisme, Politik Luar Negeri Rusia 
Since its rebirth as a sovereign state in 1 January 1992, Russia's foreign policy has been in flux and the foreign policy discourses has become ideologised (Sergunin 2004, 19-35). There are two explanations for this. First, after the demise of Marxism, Russia needed an official theoretical thinking to fill the ideological vacuum that distinct from Western theoretical view. Second, with the chronic economic crisis at home and major changes in the international environment has forced Russia to refashion its political and economic system and reemerge from a declined stature in the world stage and thus define its future role in international system. The debate on foreign policy unavoidably has been framed out of identity politics among different factions with different foreign policy orientation. The different foreign policy orientations has distinct understanding on the sources of external threats, explanation of the shift in international politics and perception of self-images toward the outside world, in answering the question who and what is Russia (Trenin 2002). Three traditions of thinking to define the identity of Russia arise in contemporary politics; Atlanticist (Westernizer), Slavophile (Nationalist), and Eurasianist (Geopolitical) (Arbatov 1994, 9-14; Kuchins and Zevelev 2012, 147-151).

Recent developments in Post-Soviet Space, particularly in Crimea and eastern part of Ukraine showed that Russian geopolitical influence again rises, while at the same time the US plus European influences in the region wanes. The growing economic rivalry for influence in the Caucasus, Central Asia and Eastern Europe between the United States plus European Union as one camp and Russia as another camp is easily could be surmised as geopolitical great game as happened in the late $19^{\text {th }}$ and early $20^{\text {th }}$ century when Eurasia region was "geographic pivot of history" (Torbakov 2004). One could argue that Russia has been struggling to regain control over the Eurasian heartland, including Central Asia and the Caucasus. As firstly coined by Harold Mackinder on 'heartland' theory, the ability to control Eurasian heartland would give the power to influence the international politics. The recent events stand to rejuvenate a long running debate over the philosophical foundation of the Russian foreign policy. Since the Soviet collapse in 1991, Russian academics and policy-makers have strived to develop grounds that could guide Russia's revival. One of the explanations is Eurasianism concept that has played prominent roles in the ongoing debate.

The Eurasianism thinking tempted Russia's foreign policy makers to embark on a development course apart from the West (Shlapentokh 2004). With its growing assertiveness and its geopolitical inclination, Russian foreign policy has been considered as a resurgence of Eurasianism or the so-called Neo-Eurasianism. Notwithstanding its strong geopolitical sense, as a matter of fact, Eurasianism is multifaceted concept. It is often associated with philosophical thinking, cultural and 
political doctrines which changed over time and yet full of contradictions. This article, therefore seeks to find out the influence of Eurasianism in Russian foreign policy. Is Russia pursuing NeoEurasianism idea? This article is divided into three parts. The first part traces back the historical roots of the idea of Eurasianism. The second part scrutinizes the contemporary Eurasianism (Neo-Eurasianism) and the rise of geopolitics. The last part examines the influence of NeoEurasianism in the Russian foreign policy.

\section{The History of Eurasianism}

The concept of Eurasia has been strongly linked to Russia identity and become the core of Russia foreign policy for centuries. In his book, The End of Eurasia: Russia on the Border between Geopolitics and Globalization, Dmitri Trenin (2002) argues that Eurasia is twin concept of spatial and political idea. Eurasia was a "political project" of Peter the Great (1672-1725) that sought to place Russia from Asia map into European map. Affected by his trip to Europe, known as the "Grand Embassy", Peter initiated a modernisation process (economic, social and military) to support his ambition to seize the Baltic coast and the Black Sea. After won the war against Charles XII of Sweden, Peter managed to draw a new geographic line that included newly won territory and moving Russia into European continent. By changing its geographic and supported with historical narrative, Peter justified the position of Russian empire as one of the established European monarchies. Thus, the identity of Russia firstly based of geographic identity.

To incorporate Russia into Europe, Visily Tatishchev, Peter's geographer, recommended the Ural Mountains as a natural boundaries to delineate the Europe and Asia continent. The problem was that method to draw the separate line between continents since ancient past was using river or sea. In the $17^{\text {th }}$ century, the geographical definition of Europe was bounded in the south by the Mediterranean Sea, in the west by Atlantic Sea, in the north by Baltic Sea and in the east by the bank of the Don (Tanais) River, an artifact of ancient Greek geography. The accuracy of the Don River as boundary between two continents had been questioned, and it paved the way to redrawing the new Europe map that would consider Russia as part of Europe, geographically, politically and culturally (Basin 2009; Schmidt 2005, 88-90). Nevertheless, the promotion of the new map had not convincingly accepted by the European monarchs. Until the era of Catherine the Great in $18^{\text {th }}$ century, Russia has not been fully accepted as a European monarch.

While Russia failed to become a truly Europe, the efforts to define Russia identity swung back to Eurasia identity. Following the failed attempt of 
Decembrist Revolution in 1825, the reform movement in Russia was marked by the emergence of intelligentsia thinking. One of the key issues that debated in that era was the position of Russia in Europe, should Russia keep on modernizing and identify itself as Europe or revitalized its unique geographic location. Eurasianism came up as an alternative thinking that would delineate Russia from Europe. There were at least two intelligentsia movements that offer this alternative vision; Slavophile and Pan-Slavism (Chaudet et al. 2009, 40-42).

Slavophile thinking was supported by educated and land-owner groups criticised the Westernization effort and conversely in favor to the true principle of Russia, Christian orthodox and Slav ethnicity. Strongly influenced by Romantic Movement from Germany at the early $19^{\text {th }}$ century, the Slavophile movement sought to restore the messianic role of Russia's Orthodox Church as the "Third Rome". As the great conflict happened at that time mostly caused by incongruent way of life between the West and the East, Russia could play as reconciliatory and promoting certain values such as solidarity and harmony as a kind of "third way" in between the West and the East (Engelstein 2009).

The defeat in Crimea war in 1854-56, and again in the Russo-Turkish war in 1878, highlighted the reality that Russian Empire was not as strong as they thought before among other Empires in Europe. This led to the emergence of Pan-Slavic movement. Pan-Slavic thinking called the unity of Slavic people despite of differences in religious, linguistic and geopolitical under Russia leadership. One of Pan-Slavic thinking proponents, Nikolai Danilevsky (2002, cited from Schmidt 2005, 90-91) defined Eurasia as a unique geographic entity separated from both Europe and Asia. Eurasia is a vast area bounded by Himalaya and Caucasus Mountain in the south and arctic in the north. Eurasia is also surrounded by Pacific Ocean in the east, Atlantic Ocean in the northwest, Black, Mediterranean and Caspian seas in the south. Thus, Eurasia characterized by independent geographical world, in between Europe and Asia but separated from Europe and Asia.

More than just geographical concept, the term of Eurasia also referred to cultural identity of the people who inhabit the Eurasia geographic. The occupation of the Mongol's golden horde in the $13^{\text {th }}$ century until Ivan III (Ivan the Terrible) proclaimed the authority of Grand Duchy of Moscow was seen as a historical moment that people of Eurasia, not only Slav but also Turk and Mongol to unite under Russia leadership. Mongol occupation lucidly isolated Russia from historical momentum that happened in Europe at that time (Renaissance and Aufklarung) that become the foundation of modernization and democratic-representative government in Europe. Nevertheless, under such "times of trouble" Russia was forced to invent economic, social and political structure that transformed Russia into unity, peaceful under centralized state, a clearly 
non-European style. Following the influence of Slavophile and PanSlavism movement which argued that the destiny of Russia did not linked to Europe, in the early of $20^{\text {th }}$ century, the Russian Tsar began to pay more attention to Asia. The conquest of Siberia, the construction of Trans-Siberia railway from Moscow to Vladivostok, and the sending millions of peasants, demonstrated the new interest of the Far East area. By exploring and occupying Siberia and the Far East area, Russia has a considerable representation of Asia. In short the mission of the Eurasianism thinking is to assemble all people together in Eurasia region within the border of the Empire under the specific values of Eurasia.

With the whole complexity of thinking about identity from the outset, the Eurasianist movement were also influenced by exile intelligentsia. Following the October Revolution 1917 there was a massive emigration of non-communist supporter such as the "whites" (Menshevik), the Anarchists, Liberals and the Cadets. Among the emigrants were intellectual that gathered in Prague and Berlin. A collection of publication by Roman Jacobson, Nikolay Trubetskoy and Piotr Savitski entitled Ishod $k$ Vostokku (Exodus to the East) marked a Eurasia movement by the intellectual émigré. It was quite surprising since the intellectuals were being in exile but still refused to integrate to the West. According to them the whole Russia's efforts to embrace the West identity was a complete fiasco mounted in the 1917 revolution, civil war and the establishment of USSR. Eurasia was seen as the only credible frontier of collective identity and as the "third way", neither socialist nor capitalist (Chaudet et al. 2009, 44-45).

The logic of third way came from Trubetskoy's main works, Europe and Mankind (1920) and The Legacy of Genghis Khan (1925). Trubetskoy admired the legacy of Genghis Khan to show how the identity of nonEuropean Russian identity. It is a fact that almost all territory of Russian empire and the USSR was once part of Genghis Khan's Mongol empire. The geographic area covering from the steppe-land in Ukraine to the pacific, and according Trubetskoy is best term as Eurasia, not Europe nor Asia. The independence of Russia in the fifteenth century was not a complete break from the "Tatar Yoke" but a continuation of a destiny that the Eurasia should united in single entity. For that reason, Russia should move to south and east to keep up the spirituality of Mongolian Ancestry and keep tight the Turanian ethnography (equivalent with Turkistan Region in Central Asia), rather than moving to the West as has been taken by Peter the Great or Lenin with his Marxism (Moore 1997, 321-340).

During 1920's the intellectual idea of Eurasianism found its golden period marked by the increasing number of membership and publication followed by the politicisation of the movement. But the movement 
gradually declined and split up following the rise of Stalin in 1929. Stalin's idea of "Socialism in One Country" attracted many members of Eurasianism to favour to Soviet state. Socialism in One Country was seen as a promotion of communism-nationalism that less influenced by Europe nationalism.

Moreover, Stalin policy to build eastern bloc in the post Second World War resemble a patriotic notion of Eurasianism. From the historical account above, Eurasianism as a classical thinking and movement could be summarise as follow, first, since Eurasianism in the first place was aimed to justify the existence and the role Russian empire in the intermonarchical system, the basic unit of the movement is not national but empire. Second, Eurasianism advocates itself as the "Third Way", by paying more attention to the eastern part of the world and negating the superiority of European style of social and political system. This thinking highlighted the importance of how Russian should percept the world as the self-consciousness to realise its identity. Providing the historical description of Russia nation, prescription of future development and strong ideological of its historical mission, inevitably, Eurasianism thinking is the final version of Russian idea (Beom-Shik 2009). Nevertheless the classical thinking of Eurasianism remained ambiguous when there has never been a definite form on how to emphasise Russia's position in the Eurasia, whether become a potential cultural and political hub between Europe and Asia or totally reject them both.

\section{Neo-Eurasia and the Rise of Geopolitics}

On the verge of the USSR broke up, Eurasianism reemerged as intellectual movement to oppose the Gorbachev's New Thinking. The Russia-Western interdependence concept brought by Gorbachev was believed made the country weakened, since Russia became dependent to other countries and losing its followers. When the USSR collapsed, NeoEurasianism was revolved into political movement and advocated across political spectrum from right to left. Graham Smith identified three most prominent and politically influential school of Neo-Eurasianism which share the same notions of Russian identity and Russian foreign policy; geopolitics. Three of them are New Right, Eurasian Communist and Democratic Statist (Smith 1999, 481-494).

\section{New Right Eurasianism}

The New Right movement emerged in the early of 1990 s as intellectual thinking and political force that opposed the rapprochement Soviet Union to the Western state through the work of important thinkers such 
as Alexander Prokhanov and Alexander Dugin in their publication in weekly journal Den (the Day) and then renamed Zavtra (Tomorrow) and Elementy. They promoted the idea of new Eurasian empire that distinguished with the Soviet Union and establish a Greater Russia by strengthening its geopolitical power by forming united Slav-Turkish community. New Right Eurasianism has some important assumptions (Tsyngankov 1998, 317-318). First, it emphasises on power as an imperative mission in international relations and neglected cooperation in a zero-sum relations between states. Second, New Right Eurasianism argues that empire is the important unit of analysis. Third, the behavior of actors in international relations is driven by both rational and nonrational tenets such as national pride, culture and national memory.

Andrei Tsygankov divides the New Right Eurasianism into two streams; moderniser and expansionist (Tsyngankov 1998, 320-334). The moderniser-Eurasianist believes that to revive Soviet Union Empire into different form and the main agenda should be focused on the economic development and military-technology. By pursuing values such as security, stability and development, a new Russian empire as the continuation of Soviet Union will be materialised. Unlike the moderniser, the expansionist does not portray itself as the continuation of Soviet Union. The most prominent thinker of the expansionist is Alexander Dugin in his journal Elementy that is available online at http://elem2ooo.virtualave.net/, and his online website http://arctogaia.com (Ingram 2001, 1029-1051; Shlapentokh 2001) He also published a book, Osnovy Geopolitiki: Geopoliticheskoe Budushchee Rosii (Fundamentals of Geopolitics: The Geopolitical Future of Russia) in 1997.

In most of his works, Dugin argues that throughout the history two types of states or empires have existed and opposed each other; the continental that associated with Roman Empire, German and Russia empires and the maritime that associated with Carthage and British Empire that nowadays evolve as the so called atlanticist. The continental empires according to Dugin described as a benevolent force that uniting vast lands and multicultural people in non-exploitative basis, and promoting virtue, tolerant and harmony as has been claimed by Russian empire in the nineteenth century. Meanwhile the atlanticist is portrayed as greedy, exploitative and self-interested driven by mercantilistcapitalism and materialistic culture.

According to Dugin, atlanticist is embodied in the behavior of the Unites States that becomes Russia's eternal enemy' (Smith 1999, 483-484). To balance and overcome the Pan American, Russia should build Eurasia geopolitical alliance as a grouping of the continental power against the sea power. While the principle adversary is the atlanticist, according to the expansionist the ultimate geopolitical and cultural threat to Russia is 
globalization, and cosmopolitanism defined as mondialism. Mondialism is a problem that comes out from Western-based chauvinistic cosmopolitanism that will undermine Russia. Gorbachev and Yeltsin are two leaders that associated with mondialism that allow the West colonises the material and cultural life of Russia in order to westernize and create a one world civilization. Therefore the mission of Russia is to unite against the mondialism, to mobilize the support from the Near Abroad, and from Islamic countries in the south.

\section{The Communist Eurasianism}

The communist Eurasianism argues that Russian will be respected internationally if it takes the golden age of Soviet era as reference. By returning to communism Russia will be fulfilling the geopolitical destiny as Eurasian power. The ultimate organizational power behind this neoSoviet version of Eurasianism is Communist Party of Russian Federation (CPRF) led by Gennady Zyuganov. This party emerged out from the hardline Communist Party of Soviet Union that committed to August coup d'état towards Gorbachev in the 1991. In 1992 it was rejuvenated and became a source of new interpretation of Russian geopolitics.

Zyuganov, following MacKinder ideas, argues that historically from Kievan Rus until now there always a continuous struggle to hold a hegemonic position as Eurasia power (Smith 1999, 486-487). Russian today's enemy is capitalist globalisation that seek to find a firm grip in Eurasia land. To resist the wave of capitalist globalisation Russia has to return to communist direction to secure economic and military strength. In the economic realm, Russia should draw the economic liberalization and turn back to denationalisation of economic combine with socialistwelfare policy, without sacrificing the geopolitical security.

To justify Russia's geopolitical mission, Zyuganov recalled the idea of patriotism and Russia's great power (Derzhava), symbolized by historical patriotic events such as October Revolution in 1917 and the great patriotic war in World War II as a representation of communist greatness. Moreover Zyuganov also highlighted communism as true identity of Russia that differentiate Russia from Europe. Thus, it is Russia destiny to re-established socialism in Eurasia land to bind the state brotherhood based on socialism and equality between nations. This idea only will be materialised of Russia as regain its strength so that be able to become hegemonic state in Eurasian land. 


\section{Democratic-Statist Eurasianism}

The Democratic Statist advocates the combination idea of western style democracy, strong state and neo-nationalism. This hybrid idea produces a geopolitical vision based on state not empire. Russia's role is to stabilise the Eurasia space and becomes a hub between Europe and Asia. Russia's goals envisaged preservation of cultural and national tradition and building cooperation among states and people in Eurasia such as Slavic, Turkic, Caucasian, Mongolian and other people within framework of national-cultural room (Smith 1999,488). The democratic-statist perceived that Russia's interest does not simply always become an antithesis of the West as Soviet Union era, but Russia should play an active role within post-Soviet space (Eurasia land).

The most important geopolitical interests, inevitably is the Near Abroad (Blizhnee Zarubezhe). The Near Abroad is a concept used by Russia to depict the other 14 republics of Soviet Union. The term Near Abroad also used to delineate with the term Far Abroad that is Central Europe. The Near Abroad is a political construction of geographical boundaries that tied up the memory of Russia's past greatness, Russia economic and security interests, and the dispersion of Russia ethnic. However, different with New Right and Communist Eurasianist, the role of Russia in the Near Abroad not as imperial but as a great power state. By imposing the role of the state rather than imperial means that there will be a legitimate behavior in pursuit the state's interests toward its neighbor within the norms of the state system not based on a policy of domination (Beissinger 1995, 167).

The importance of the Near Abroad is first, based on the natural permeability of Russia's border (Smith 1999, 489). Border in Russia is understood in two concepts, internal borders and external borders. The internal borders refer to Russia Federation state's border while external borders comprising a whole Eurasia land. The internal and external borders are related since a conflict in a region will easily turn into a geopolitically unstable in a whole region. For example, when the war on Chechnya broke out, it destabilised Transcaucasia, Georgia and Lithuania that also dragged into secessionist war. The DemocraticStatist defined those conditions as a "geopolitical vacuum" and advocates to reassert Russia's role over the Near Abroad.

The importance of Near Abroad is also predisposed by Russia's economic interests to prompt the political and economic integration within the CIS. By returning the economic integration of the ex-Soviet states, Russia will gain a higher profile in the global economic affairs, and it will become an opportunity for Russia's comes back as a Eurasian geopolitical power. Finally, the Near Abroad also concerned with the dispersion of Russian ethnic that counted more than 25 million. In 
several countries, Russia Diaspora encountered citizenship problems such as in Estonia, Latvia and Ukraine, that needs an active and interventionist role of Russia to settle this problem (Vuskharnik 2010).

To sum up, the spread of Neo-Eurasianism in the political spectrum emerged as the result to the detriment of Western-atlanticist orientation. All version of the Neo-Eurasianism remark that Russia is witnessing a weakening of the country and Russia becomes dependent to the external power. Therefore, the Neo-Eurasianists intend to rectify the Russia's international status through combination of nationalism and geopolitical appeal to define the Russia identity and Russia national interest in the formulation of diplomatic and foreign policy.

\section{Neo-Eurasianism and Russian Foreign Policy}

Russian foreign policy after the collapse of Soviet Union has been transformed conforming to Kozyrev doctrine, Primakov doctrine and Putin doctrine. Kozyrev doctrine which was adopted in the first term of Yeltsin era defines Russia's identity as the new liberal democracy and market economy along with the Western-centered system. First Yeltsin's Foreign Affairs Minister, Andrey Kozyrev underlined that the rejoining to the West as a "return to civilization" to support the Russia's transition to democracy and market economy (Smith 1999, 482). However, the socalled atlanticist foreign policy orientation faced significant challenges from domestic politics showed in the result of parliamentary (Duma) election in 1993 and 1995 that elevated Zhirinovsky's LDP and Zyuganov's Communist party as majority power.

Moreover, when NATO decided to expand its membership to embrace ex-communist countries in the Central and East Europe, it attacked the sense of prestige of Russia (Baranovsky 2010). The NATO expansion had forced Russia to change the perception of the world politics and therefore redefine its identity and its national interest in international system. Neo-Eurasianism then gained popularity since it declared as a new identity drawn from Russia's tradition as great power, unique multi culture and distinguished tradition compare to Europe and Asia.

The inclination towards Neo-Eurasianism was represented by the emergence of Primakov doctrine. Yevgeny Primakov was Russia Foreign minister in 1996. From September 1998 to May 1999 he became prime minister, before he was replaced by Vladimir Putin. The Primakov doctrine introduced serious attempts to restore Russia's lost prestige and international stature. Rhetorically, it seeks to continue Russia's great power position in the world, follow a multipolar policy against United States' tendency towards unipolarism and highlighted the importance of 
realist and pragmatic policy (Ersen 2004, 144). Nevertheless there was a wide gap between ideal thinking and the actual capability of Russia, so that until that period the new wave of Eurasianism never been taken seriously by the West.

The ascension of Vladimir Putin to presidency in January 2000 prompted the consolidation of Primakov doctrine into grand strategy. From the outset, Putin showed its closeness to multipolarism and NeoEurasianism idea. The Russia foreign policy concept of 2000 declared that Russia had a deep anxiety with growing unipolarity of international system under the United States domination. It is also stated that Russia will achieved a firm and prestigious position in the world community as one of the most influential centers in the world (www.fas.org/nuke/guide/russia/doctrine/econcept.htm). In a speech in July 2000, Putin also said that he would do anything to restore the position of great power in Russia, while in other speech he said that Russia always felt itself to be a Eurasian country (Ersen 2004, 147). Interestingly, Putin also showed his militaristic vision to make a solution over Chechnya, criticized the NATO enlargement and made a close relation with the United States' enemy such as China, Cuba, North Korea and Iran. From his first step, Putin was applauded by all Eurasianists supporters.

Nevertheless, Putin shocked the Neo-Eurasianist supporters when he declared a "strategic partnership" with the United States following the 9/11 events. Furthermore, Putin allowed the using of Central Asia as military bases for the United States military in attacking Afghanistan. For the eurasinist supporter Putin has swung his orientation to atlanticist and betrayed the spirits of Russia's great power (derzhava) and Eurasianism. Dugin (2002 cited from Ersen 2004, 152), for example criticized that the campaign against terrorism was only used by the United States to weaken the anti-globalist movement to ensure the unipolarity world order.

However beyond the surface, Russia involvement in war against terrorism was driven by pragmatic strategy to solve Russia's domestic problems (Emre Ersen 2004). First, Russia needed legitimacy, at least from Western perspective relating to war on Chechnya. By linking the Chechnya separatism with Wahabism and Osama Bin Laden, Russia reduced any complaints from international community regarding to human rights abuses. Second, although permitting the United States to build military bases in Uzbekistan, Kyrgyzstan and Tajikistan, Russia had a chance to strengthen its influences in Central Asia by establishing Shanghai Cooperation Organisation (SCO) without any serious contention from the United States. Third, the rapprochement with the United States would ease Russia to make political maneuvers towards Georgia that backed by the United States. 
Jeffrey Mankoff (2006) also offered an interesting explanation on the Russia-US rapprochement. According to Mankoff, Putin was pragmatically employ peredhyska or breath-catching strategy. It is a strategy that emphasise a pragmatism, flexibility and cautiousness to recover the country's strength. This strategy basically is seeking a global stability, while internally there was a room to take a breath and prepare itself. Historically this strategy was adopted by Tsar Alexander II and Aleksandr Gorchakov after the Crimean War, and again by Sergei Witte, Pyotr Stolypin, and Aleksandr Izvolsky following the Russo-Japanese War and the 1905 Revolution (Mankoff 2006). In the recent Russia context peredhyskha strategy could be seen on how Putin seek to consolidate internal condition of Russia by re-holding a firm control over the federation, control the Duma by guarantee the domination of United Party, battling the untamed oligarchs such as Gusinsky and Khodorovsky and control the press. By reducing the tension with the United States will make the internal adjustment goes smoother. Thanks to the rise of oil price that accelerate the Russia's economic recovery. Soon afterwards Putin went back to great power and geopolitical appeal.

Throughout 2005-2006, the world saw the re-emergence of Russia as an assertive actor in global affairs. Triggered by NATO's plan to grant membership towards Ukraine and Georgia in 2006, Putin strongly spoke against the expansion. From Russia's perspective, by accessing Ukraine and Georgia, NATO is assuming Russia as its potential enemy. Russia also perceived of being cheated by the United States regarding the strategic arms treaty.

In START (Strategic Arms Reduction Treaty) I and II the two countries agreed to reduce its nuclear war head weapon to almost 30\%. However, the United States cancelled its commitment on ABM 1972 treaty to keep on develop the National Missile Defence Program (NMD). The ABM 1972 is a part of SALT (Strategic Arm Limitation Talks) that prohibits each party to develop anti-ballistic missile. Furthermore the United States planned to develop the anti-ballistic defence in Czech and Poland that could be easily interpreted as protecting Europe from Russia's missiles. Reacting to this development Putin said that the United States has turned to be "a wolf which knows who to eat and is not about to listen to anyone" (Smith 2007, 1). Russia's growing assertiveness shown by the demise of strategic partnership with the United States that changes the relation to become 'agree to disagree' and 'agree to oppose', just like old US-Soviet time.

It was also clearly portrayed in the growing geo-political orientation such as, Russia's supports to authoritarian regime in Central Asia to gain influences, Russia-Ukraine conflict over gas price and political intervention in presidential election, and Russia military attacked to Georgia in 2008. Neo-Eurasianist vision mounted in the involvement in 
Ukraine crisis in 2013 that led to Crime irredentism to Russia and the ongoing separatism in eastern part of Ukraine.

The recent development at glance it looks like echoing the geopolitics vision of Neo-Eurasianism, but beneath the surface it also reflects a pragmatic-economic vision rather than the whole spirits of Eurasianism; first related to energy policy such as oil and gas production, transportation, and export; and second, related to economic integration of Eurasian countries that offers a huge market to Russia. While Russia export and investment are heavily depending on European market, it would resist Russia from separate itself from Western-Atlantic countries (Chaudet et al. 2009, 61-62). What is surely comes up from recent Russia's foreign policy is a compromise policy that integrate Westernatlanticist elements, patriotic elements and classical Eurasianism elements into a pragmatic-realistic blend.

\section{Conclusion}

The Eurasianism idea once again emerged out following the collapse of the Soviet Union. Under the banner of Neo-Eurasianism, it cast to fulfil the ideological vacuum, the lost identity and the demise of international status. It spreads out in political spectrum from left to right as criticism to infatuation of Western oriented foreign policy. The rise of NeoEurasianism in Russia's foreign policy is driven by the needs to define and strengthen the spheres and influences and the needs to construct a foreign policy consensus based on political culture and national awareness.

What seem to evolve in Russia's foreign policy today is an inclination to compromising the pattern of thinking among different foreign policy orientation. Russia's foreign policy under Vladimir Putin shows an integrationist policy that is trying to bind all political trends in Russia. Therefore, Putin also best defined as democratic-statist Eurasianist, according to Graham Smith category. In this kind of blend policy, the influences of Neo-Eurasianism are shown in economic aspects and geopolitical aspects rather than a whole spiritual vision of Eurasianism. The Russia's interest towards Near Abroad, Islamic world and Asia somewhat shows a clear evidence of Neo-Eurasianism appeals. However it is worth noting that the recent Neo-Eurasianism is not driven by an imperial motive but more associate to nationalism or pseudoimperialism best defined as great power aspiration. The consequence of this point is that the geopolitical movement of Russia does not lead to the dream of enlarging the territory of Russia, but mainly driven by ethnocentric sentiments to expand the sphere of influences across the border as a safeguard and protection to the identity within the borders. 


\section{Reference List}

\section{Books and Book Chapters}

Chaudet, Didier, et al., 2009. When Empire Meets Nationalism; Power and Politics in the US and Russia. Farnham: Ashgate.

Engelstein, Laura, 2009. Slavophile Empire; Imperial Russia's Illiberal Path. Cornell: Cornell University Press.

Trenin, Dmitri, 2002. The End of Eurasia: Russia on the Border between Geopolitics and Globalization. Washington D.C: Carnegie Endowment for International Peace.

\section{Journals and Periodicals}

Arbatov, Alexei, 1993. "Russian Foreign Policy Alternatives", International Security, 18 (2): 9-14.

Beom-Shik, Shin, 2009. "Resurgence of Eurasianism and the Future of Eurasia: A View from the East", Paper presented at the conference Eurasianness and National Identities in the Post-Soviet Era, Seoul: Asia-Pacific Research Center Hanyang University, June 18-19.

Beissinger, Mark, 1995. "The Persisting Ambiguity of Empire", PostSoviet Affairs, 11: 149-184.

Ersen, Emre, 2004. "Neo-Eurasianism and Putin's Multipolarism in Russia Foreign Policy", Turkish Review of Eurasian Studies, Annual 4: 1-34.

Ingram, Alan, 2001. "Alexander Dugin: Geopolitics and Neo-Facism in Post-Soviet Russia”, Political Geography, 20: 1029-1051.

Kuchins, Andrew, C. and Igor A. Zevelev, 2012. "Russian Foreign Policy: Continuity in Change", Washington Quarterly, 35 (1): 147-161.

Mankoff, Jeffrey, 2006. "Vladimir Putin and the Re-Emergence of Russian Foreign Policy", International Security Studies Certificate Paper Series Number 06-02, Yale University, Department of History.

Moore, David Chioni, 1997. "Colonialism Eurasianism, Orientalism", SEEJ, 41 (2): 321-240.

Sergunin, Alexander A., 2004. "Discussion of International Relations in the Post Communism Russia", Communist and Post-Communist Studies, 32: 19-35. 
Schmidt, Matthew, 2005. "Is Putin Pursuing a Policy of Eurasianism?" Demokratizatsiya, 13(1): 87-99.

Smith, Graham, 1999. "The Mask of Proteus: Russia Geopolitical Shift and the New Eurasianism", Transactions of the Institute of British Geographers, 24 (4): 481-494.

Smith, Mark A., 2007. "A Review of Russian Foreign Policy”, Defense Academy of the United Kingdom, July.

Trenin, Dmitri, 2006. "Rusia Leaves the West", Foreign Affairs, JulyAugust 85 (4),: 13-18.

Tsyngankov, Andrei P., 1998. "Hard-Line Eurasianism and Russia's Contending Geopolitical Perspectives", East European Quarterly, 32, (3): 320-334.

\section{Internet Websites}

Baranovsky, 2010. Vladimir, "NATO Enlargement: Russia's Attitude" [online].

http://se1.isn.ch/serviceengine/Files/ISN/22221/ichaptersection_s ingledocument/B5AC9791-EF70-4206-A749-

EE68769C4FB7/en/NATO_Enlargement_2.pdf [downloaded 15 August 2014].

Basin, Mark, 2009. "Classical Eurasianism and The Geopolitics of Russian Identity” [online].

http://cesran.org/Dosyalar/MAKALELER/MARK_BASSIN_CLASS ICAL_EURASIANISM_AND_THE_GEOPOLITICS_OF_RUSSIAN _IDENTITY.pdf [downloaded 15 August 2014].

Shlapentokh, Dmitri, 2001. "Russian Nationalism Today: The View of Alexander Dugin”, Contemporary Review, July [online].

http://findarticles.com/p/articles/mi_m2242/is_1626_279/ai_777 12793/ [downloaded 15 August 2014].

Shlapentokh, Dmitri, 2004. "Russia's Foreign Policy and Eurasianism" [online].

http://www.eurasianet.org/departments/insight/articles/eavo8020 5a.shtml [downloaded 15 August 2014].

Torbakov, Igor, 2004. "Reexamining Old Concepts about the Caucasus and Central Asia" [online].

http://www.eurasianet.org/departments/insight/articles/eav02040 4a.shtml [downloaded 15 November 2014]. 
Vuskharnik, Anton, 2010. "Russian Baltic policy: The Song remain the same" [online].

http://www.bmlv.gv.at/pdf_pool/publikationen/o9_sgb_o6_rbp.p df [downloaded 10 November 2014].

“The Foreign Policy Concept of Russia Federation” [online] www.fas.org/nuke/guide/russia/doctrine/econcept.htm [downloaded 10 November 2014] 